\title{
Religious resistance and secular politics Laying the foundations of the Indonesian state $(1945-1947)$
}

We didn't want to leave West Java behind, we didn't want to see the ummah and the Indonesian people in West Java become slaves of the evil Dutch, we didn't have the heart to listen to the moans of the Republicans who wished to retreat to Yogya[karta]. [...] for whom were we withdrawing to Yogya? And what would we do, then, if the Dutch took Yogya as well? What would be the fate of the people left behind? Wasn't that a betrayal? [...] Eventually, with resolute hearts, we decided not to join the withdrawal to Yogya and to continue instead the resistance against the occupying Dutch soldiers, joining the Sabilillah group in West Java. ${ }^{1}$

Japan had made new concessions to Islamic groups in the social and religious fields, but it quickly stepped back when it came to determining the position of Islam in the new state, fully delegating the definition of such relation to local leaders. In late April 1945 Japan formed the Komite Nasional Indonesia Pusat (KNIP, Preparatory Committee for Independence), with the intention of initiating a debate about the ideological foundations of the future Indonesian state. On an increasingly dynamic political stage, the inexperienced leaders of Muhammadiyah, Nahdatul Ulama and Masyumi were quickly sidelined by the nationalist elite. When in May the debate became polarized around the question of whether Indonesia should be an Islamic or a secular state, Soekarno's camp emerged as the winner. ${ }^{2}$

The conclusive speech, delivered by Soekarno on 1 June, ignored the controversy that had dominated the committee's sessions and proclaimed, in the name of national interest, unity and harmony, that Indonesia was to be built on the Pancasila, or the five

1 Confession of Sjarif Hidajat, Darul Islam member, arrested on 2 July 1961. 'Confession letter of Sjarif Hidajat, former member of Kartosuwiryo's group', 10 September 1961, Penumpasan DI-JaBar, [folii], Arsip Angkatan Bersenjata Republik Indonesia [hereafter AABRI DI], Jakarta.

2 Benda, The crescent and the rising sun, pp. 169-94 and pp. 179 onwards. 
principles of kebangsaan (nationalism), perkemanusiaan (humanitarianism), permusyawaratan-perwakilan (deliberation among representatives), kesejahteraan (social welfare) and ketuhanan (belief in One God).$^{3}$

A smaller committee was arranged to address the complaints coming from the Islamic faction and to ease emerging frictions. On 22 June the participants reached a common declaration meant to serve as the new constitution's preamble. While it did not recognize the idea of an Islamic state, this version of the constitution accepted sharia law by affirming 'the obligation for adherents of Islam to practise Islamic law'. ${ }^{4}$

This clear reference to Islam in the constitutional preamble prompted a reaction from the Christian representatives, and that sentence - later to become known as the Piagam Jakarta (Jakarta Charter) - disappeared from the final draft presented on 13 July, being replaced instead with a declaration of freedom of religion. The members of the Islamic faction had intended to further debate these changes, but as Japan was losing ground in the Pacific and would soon capitulate, Indonesian politicians felt compelled to accelerate their preparations for independence and to work with what they had. By 7 August the committee had been cleansed of all Japanese members, and on the 11th, in the aftermath of the explosion of the atomic bombs in Hiroshima and Nagasaki, Japan reassured Soekarno and Hatta that independence would be granted on the 24th of that month.

This chapter analyses the end of Japanese rule in Indonesia, the return of the Dutch and the dynamics surrounding Soekarno's establishment of the Indonesian Republic. I focus in particular on Masyumi's reaction to Soekarno's decision to declare Indonesia a non-confessional state and on his readiness to re-engage in diplomatic talks with the Dutch. Kartosuwiryo had been sidelined in 1944, but we see him now returning to the political scene, first as Masyumi's executive committee secretary (in 1945), and then as a party representative at the KNIP (1946 and 1947) and a candidate for the post of junior Minister of Defence (July 1947).

3 Boland, The struggle of Islam, pp. 15-23; Herbert Feith and Lance Castles (eds), Indonesian political thinking, 1945-1965 (Ithaca: Cornell University Press, 1970), pp. 40-9.

4 'dengan kewadjiban mendjalankan Sjari'at Islam bagi pemeluk-pemeluknja'; see Soekarno, Hatta et. al., 'Piagam Jakarta: Preamble to Undang-Undang Dasar Republik Indonesia 1945', in Greg Fealy and Virginia Hooker (eds), Voices of Islam in Southeast Asia (Singapore: ISEAS, 2006), pp. 209-10. The members of the committee were Soekarno, Hatta, A.A. Maramis, Abikoesno Tjokrosoejoso, Abdoelkahar Moedhakkir, H. Agoes Salim, Achmad Soebardjo, Wahid Hasjim and Moehammad Jamin. 
Kartosuwiryo's base was still the Priangan, and when the Dutch launched their invasion of West Java in July 1947, he rejected any further involvement in national politics in favour of organizing the defence of his region. It was in the midst of this invasion that Kartosuwiryo transformed the West Java branch of Masyumi into the Darul Islam group, setting aside his commitment to the parliamentary struggle, an effort that he had renewed as recently as August 1946.

At the national level, in the years following the Japanese capitulation, Masyumi would become more insistent in its demands for an Islamic state, also calling it a darul Islam. In 1945 the Party proclaimed armed resistance to the Dutch a jihad, and occasionally Masyumi took an aggressive stand against the Republican administration. Political clashes soon had their counterpart on the battle ground, as Republican troops and Islamic militias tended to keep separate. The Dutch invasion and the ensuing treaty (the Linggadjati Agreement) further heightened tensions, as West Java was declared de facto Dutch territory, thus establishing the end of Republican authority over the region.

SHIFTING CENTRES OF POWER: TOKYO, JAKARTA, LONDON, THE HAGUE

Japan's plan to transfer sovereignty to Indonesian leaders was halted by its defeat in World War II. Japan surrendered on 15 August, and the Allied forces, on behalf of the South East Asia Command (SEAC), took control of the Pacific front immediately thereafter. Yet as the British were unable to land until late September, Java was left to its own fate as a contested space between the retreating Japanese, the Indonesian nationalists and the re-invading Dutch troops. ${ }^{5}$ The enthusiasm that had swept across the archipelago at the Japanese landing was experienced by neither the SEAC nor the Dutch troops.

The news of Japan's surrender took weeks to seep through and out of Jakarta, fomenting unrest and chaos between diplomacyoriented politicians and revolution-minded pemuda (youth). The first and perhaps most significant of such incidents was the kidnapping of Soekarno and Hatta by a group of radical nationalists who wanted independence declared before Japan transferred authority to the Allies.

5 For a detailed account of the British occupation, see Richard Mcmillan's, The British occupation of Indonesia, 1945-1946 (London: RoutledgeCurzon, 2005) and 'British military intelligence in Java and Sumatra, 1945-46', Indonesia and the Malay World 37-107 (2009). 
Soekarno proclaimed independence on 17 August without the support of Soetan Sjahrir, who was head of the underground anti-Japanese movement, or that of the Islamic wing, which demanded a more prominent role for religion. Hatta chaired a final informal meeting of the preparatory committee on 18 August and concluded that Indonesia only had a chance as an independent nation if no mention of Islam was made in the constitution.

The Jakarta Charter was excluded from the final version of the Indonesian constitution, and to placate the Islamic nationalists, Soekarno specified that this constitution was 'temporary', 'quick' and only applicable to the revolution (sementara, kilat, revolutiegrondwet). Soekarno also promised that 'later in the future [...] if we live in a safe and orderly state, we will gather once again the elected representatives of the people, who will enable us to make a more complete and perfect constitution'. ${ }^{6}$ Soekarno's failure to follow up on the 'temporary' aspect of the constitution deeply informed Kartosuwiryo's decision to proclaim the Negara Islam Indonesia in 1949.

In the weeks following their surrender, the Japanese were still in charge. The British commander requested, albeit unsuccessfully, that all internees remain in the camps, so as to avoid the spread of vengeful violence. Lawlessness was rampant in the towns and the countryside, with the Japanese, Europeans and Chinese becoming the favourite targets of local gangs. Jakarta was the centre of a struggle for power among the Dutch, Japanese and Indonesians, in the midst of which British troops quietly mediated to re-establish law and order. On the political front, Soekarno and Hatta acted as if the proclamation had been forced upon them. They did very little to establish government structures, instead focusing on diplomacy and leaving most of the action to the so-called laskar (militia), both in Jakarta as well as in the neighbouring areas. The apex of this conflict in strategy was reached in mid September, when Soekarno interrupted a mass rally in the capital with calls for peace and order instead of showing his support for the revolutionary intent of the demonstrators.

By the end of the month, the Japanese mayor had indirectly handed over control of the city to his Indonesian counterpart, Suwiryo, and Dutch attempts to regain it were stonewalled by the

6 Endang Saifuddin Anshari, Piagam Jakarta 22 Juni 1945: Sebuah konsensus nasional tentang dasar negara Republik Indonesia 1945-1959, 3rd ed. (Jakarta: Gema Insani Press, 1997), p. 48. A recent discussion of the Jakarta Charter and its current impact on Indonesian politics can be found in Nadirsyah Hosen, Shari'a and constitutional reform, pp. 59-69. 
Allies, who insisted that the Dutch not re-take political control. An official Dutch municipal administration was not constituted until February 1946. In the latter part of 1945 Jakarta functioned as the formal capital of both the Indonesian Republic and the Netherlands Indies, its de facto control being a crucial step on the road towards de jure authority over all of Java, if not over the entire former East Indies' territory. But when British troops succeeded in bringing the city under total control in December, most laskar fled the town, and the Republican government gradually withdrew to Central Java, leaving Jakarta in the hands of the Europeans. ${ }^{7}$

Within weeks of the Japanese surrender, before the British assumed control of Jakarta, Soekarno had already formed the first Republican cabinet. Having transformed the KNIP into a legislative body, Soekarno called on Indonesians to form political parties and to begin preparations for parliamentary elections, scheduled for the following year in January. The nationalist front was far from united, and in October the socialist Soetan Sjahrir released his Perjuangan kita (Our struggle) pamphlet, indirectly accusing Soekarno of cooperation with the Japanese and of displaying sympathies for Tan Malaka. Tan Malaka was the leader of the communist group, who, it had emerged, had in October and November been preparing for a coup. To avoid the potentially destabilizing alliance of Sjahrir with Tan Malaka, in mid November Soekarno offered Sjahrir the opportunity to form the cabinet.

The post-World War II reorientation of the nationalist movement was evident to Van Mook as soon as he landed on Java in October 1945. The Lieutenant Governor-General realized that the Japanese occupation had strengthened the nationalists to the point that their struggle for independence had gained too much momentum to be restrained by military force. Restraining the movement was even less tenable because the Netherlands would have had to rely on British troops, which had neither an interest nor a stake in reinstating Dutch colonial rule. Further widening the existing rift between Jakarta and The Hague, Van Mook initiated talks with the nationalist leadership, as he saw a viable solution only in diplomacy. More importantly, he saw the solution in recognizing the different status of Java vis-à-vis the rest of the archipelago, as the Netherlands had indeed succeeded in restoring pre-war order in the eastern islands. ${ }^{8}$

7 Robert Cribb, 'Administrative competition in the Indonesian revolution: The dual government of Jakarta, 1945-1947' in The Indonesian revolution, pp. 129-46.

8 J.J.P. de Jong, 'Winds of change: Van Mook, Dutch policy and the realities of November 1945', in The Indonesian revolution, pp. 163-82. 
The Allies had been quite explicit in their unwillingness to negotiate with a former collaborator of the Japanese (meaning Soekarno), and so it was that the recognition of Sjahrir's cabinet as representative of one portion of the Indonesian archipelago and his voluntary agreement to a federation with tight connections to the Netherlands made it possible, in late 1946, the signing of the Linggadjati Agreement.

In the window between the Japanese defeat and the Dutch return, the political scene changed dramatically. The largest party during this time was the new Partai Nasional Indonesia (PNI), which, its name notwithstanding, had nothing to do with Soekarno's party, as it represented professionals and civil servants. However, the party with the widest and deepest support in late 1945 - and until the end of the decade - was Masyumi, which had reorganized itself in November. The next party to form was the Partai Sosialis (Socialist Party), which was established in December and included both Amir Sjarifuddin's and Soetan Sjahrir's constituencies. Several other parties were founded in 1946, yet only these three played significant roles during the revolution and in the early years of the Republic.

In the months following the Indonesian proclamation of independence, Kartosuwiryo regained his position as secretary of Masyumi's executive committee, and he was also chosen as party representative for the KNIP general assemblies in 1946 and 1947, and for its Working Committee (Badan Pekerja) in 1947. ${ }^{9}$

At the November 1945 congress, former Sarekat Islam and Partai Islam Indonesia (PII) members dominated the central board, whilst NU and Muhammadiyah leaders were only found in the Majelis Sjoero (consultative assembly). The boards of the two departments were a bit of a potpourri, with Agoes Salim and Mohammad Roem from the Awareness Committee sitting next to Kartosuwiryo, Muhammad Natsir, K.H.A. Sanoesi, and K.H. Abdoelwahab. ${ }^{10}$ In the meantime Muhammad Natsir acted as vicepresident of the KNIP working committee. ${ }^{11}$ This fragmentation of the membership of the core bodies of the party created the conditions for Masyumi's political incoherence in the 1950s. As

9 D. Noer and Akbarsyah, K.N.I.P.: Komite Nasional Indonesia Pusat. Parlemen Indonesia 19451959 (Jakarta: Yayasan Risalah, 2005).

10 Deliar Noer, Masjumi: its organization, ideology and political role in Indonesia (master's thesis, Cornell University, Ithaca, 1960).

11 'Overzichten van berichten betreffende het republikeinse leger in de Maleise pers van West-Java 1945 Oktober-1946 April', p. 59, AMK: Supplement (1664) 1826-1952 [hereafter Supp] no. 78, NA. 
old fractures had not yet healed, it is not surprising that Masyumi failed to bring about a defined platform for Indonesia's independence in Islamic terms. Within a year, the leadership would change dramatically. ${ }^{12}$

In the period following the SEAC occupation of Java, three dynamics - Soekarno's neglect of Islam, the Republic's weakness in asserting its sovereignty against Dutch claims, and Masyumi's lack of a political strategy to gain a more dominant position in national politics (despite its large following) - led to the Islamization of the ideological struggle as well as the polarization of Republican and Islamic troops on the territory of West Java.

MASYUMI'S ISLAMIZATION OF THE IDEOLOGICAL STRUGGLE

In early October 1945 the Poentjak Pimpinan Masjoemi Batavia (Masyumi Jakarta Leadership Summit) declared a perang sabil against the Japanese and the Netherlands Indies Civil Administration (NICA). According to a Dutch overview of the Malay press in West Java, Masyumi was calling upon Indonesians to work towards unifying religion and state. ${ }^{13}$ This call was not an isolated case.

While Van Mook was informing The Hague that nationalist groups in Java had radicalized, displaying 'hard fanaticism', Kiyai Haji Hasjim Asj'ari, founder and chairman of Nahdatul Ulama and now chairman of Masyumi's Majelis Sjoero, issued a declaration of holy war against the Dutch. Published on 20 November 1945 in Kedaulatan Rakyat, ${ }^{14}$ this declaration called upon all Muslims to defend the newly independent Indonesia from the 'infidels who obstruct our independence' and the NICA. Such a defence was declared an individual duty (fard at'ain), and whoever died in the

12 Dewan Partij: Soekiman, from its PSII splinter Partai Islam Indonesia, was the chairman, with Abikoesno (PSII) and Wali al-Fatah (PII) as his vices; Harsono Tjokroaminoto (PSII) and Prawoto Mangkoesasmito (SIS) were the secretaries. Majelis Sjoero: KH Hasjim Asj'ari as chairman, Ki Bagoes Hadikoesoemo, K. Wahid Hasjim and Kasman Singodimedjo as vice-chairmen. Masjoemi, Partai Politik Islam Indonesia (Bukit Tinggi: Dewan Pemimpin Daerah Masjoemi Soematra Barat). This pamphlet was most probably printed on the occasion of the 22 April 1946 congress.

13 'Overzichten van berichten betreffende het republikeinse leger in de Maleise pers van West-Java 1945 Oktober-1946 April', p. 34, AMK: Supp no. 78, NA.

14 Kedaulatan Rakyat [hereafter KR], 20 November 1945 in Amiq, 'Two fatwas on jihad against the Dutch colonisation in Indonesia: A prosopographical approach to the study of fatwa', Studia Islamika 5-3 (1998), p. 86. 
fighting was to be a martyr. ${ }^{15}$ At the Nahdatul Ulama congress, held in March 1946, it was decided that all Muslims - men and women, adults and children, armed and unarmed - living within a $94 \mathrm{~km}$ radius from occupied areas had the individual religious duty to fight the Dutch. For those living outside the given distance, theirs was instead a collective duty (fard al-kifaya). ${ }^{16}$ The legal grounds for this resolution were found in the fact that Indonesia had been declared 'land of Islam', dar al-Islam, in 1936, making the defence of its territory and population against infidel invasions wajib. ${ }^{17}$

Asj' ari's fatwa also announced that 'whoever divides our unity is liable to be killed'. The view that 'splitters' should be equated with apostates was derived from the idea that whoever undermined a united front was 'a Dutch agent'. It is not far-fetched to suggest that this was a veiled accusation of the nationalists' readiness to cooperate with Dutch colonial authorities. ${ }^{18}$

The modernist wing, in charge of Masyumi's central board, was reluctant to endorse Asj'ari's fatwa, declaring a jihad against the Dutch, and to call the whole community to such a duty. The central congress had already rejected a motion proposed by the Kaoem Moeslimin Indonesia Angkatan Sendjata (Indonesian Muslims Armed Group) to declare 'war on the way of God' (jihad fi-sabilillah) a collective religious duty. ${ }^{19}$ However, it felt compelled to endorse the pressures advanced from several quarters ${ }^{20}$ and supported the plan to prepare the Islamic community for such a jihad. ${ }^{21}$ To show

15 Islamic fiqh categorizes actions in five groups: haram (prohibited), makruh (contemptible), mubah (permitted), mustahabb or sunnah (recommended). The wajib/fard (obligatory) actions are further distinguished between those that pertain to the individual (fard al- ayn) or those that fall upon the entire community (fard al-kifaya).

Nahdatul Ulama literature refers to the 'jihad resolution' as being released either at the NU Java and Madura congress held in Surabaya on 22 October 1945, or possibly at the Central Java congress held in Purwokerto from 26 to 29 March 1946. al-Djihad, 2 April 1946; Amiq, 'Two fatwas on jihad', pp. 87-9.

16 'Resoloesi tentang djihad', al-Djihad no. 30, 2 April 1946.

17 This opinion was given by Shaykh Muhammad Salih al-Ra'is, who is described by Amiq as the mufti of the Hadramis, via a fatwa that was later sent to Nahdatul Ulama leaders. The fatwa was eventually approved by the NU Banjarmasin congress in 1936; Amiq, 'Two fatwas on jihad', pp. 90, 108-9.

18 This approach is explicit in Kartosuwiryo's 1949 ad-Daulatul Islamiyah and Manifesto politik no. $1 / 7$, in which Republican leaders and supporters are accused of being 'Dutch agents', and thus enemies of war.

19 'Kaoem Moeslimin Indonesia Angkat Sendjata', KR, 15 October 1945.

20 During the khutba for Idul Adha (mid November 1945) in Bandung, Kiyai Abdoessalam had called on the large crowd to fight a holy war against the Netherlands; in 'Militaire, politieke en economische gegevens uit de Maleise pers betreffende de residenties Batavia, Buitenzorg, Krawang, Bandung, Surakarta, Djokjakarta, Semarang en Kedu', p. 11, AMK: Supp no. 76, NA. 21 '60 Miljoen kaoem Moeslimin Indonesia siap berdjihad fi Sabilillah', KR, 9 November 1945. 
its support of this plan, the congress decided in favour of creating a new armed wing, the Sabilillah (lit. 'on the path of God'), which was a special corps of the Tentara Keamanan Rakyat (TKR, People's Security Army) placed under the direct supervision of Masyumi to support the already active Hizboellah. ${ }^{22}$

These steps confirmed the party's general understanding of jihad as a duty to be pursued only by a portion of the population namely, the armed-youth wings - whilst the rest of the population was to concentrate on 'studying the social sciences' and entering the world of politics. Studying and engaging in politics were crucial as Masyumi leaders believed that change was only possible through political action. ${ }^{23}$ As Harun Nasution has argued, the modernists sought to create an Islamic state by first preparing its society, whilst the traditionalists believed it impossible to create an Islamic society without first establishing the appropriate government structures. ${ }^{24}$ In the revolutionary context of 1946, this distinction was to become blurred, and Kartosuwiryo's explanation of Masyumi's strategy will show the uncompromising primacy of independence.

Masyumi's dedication to establishing an independent Islamic state was constantly emphasized in the pages of its bulletin al-Djihad. Beginning in February 1946, this periodical conducted a propaganda campaign in support of a holy war, the hijrah policy and an Islamic state, or darul Islam. On 13 February it celebrated the prophetic migration to Medina and Muhammad's defence of the Islamic city-state as models of political action, suggesting that readers should rise in an Islamic revolution as a free and independent ummah 'demanding freedom for its religion, people and islands'. ${ }^{25}$

This same month, the party congress unveiled the two pillars of its political agenda: an unshakable dedication to the formation of a darul Islam, that is an Islamic state, and a commitment to do so through parliamentary consultation. This approach was reaffirmed

\footnotetext{
22 'Barisan Sabilillah', KR, 17 November 1945.

23 'Masjoemi, toelang poenggoeng Republik Indonesia', al-Djihad no. 26, 28 February 1946. Members of the Masyumi branch in Cicalengka were reportedly shouting - during a party meeting in early January - 'Freedom and paradise'; in: 'Militaire, politieke en economische gegevens uit de Maleise pers betreffende de residenties Batavia, Buitenzorg, Krawang, Bandung, Surakarta, Djokjakarta, Semarang en Kedu’, p. 16, AMK: Supp no. 76, NA.

24 Harun Nasution, 'The Islamic state in Indonesia: The rise of the ideology, the movement for its creation and the theory of the MASJUMI' (master's thesis, McGill, Montreal, 1965, pp. 76-7).

25 'Revoloesi Islam', al-Djihad 24, 13 February 1946. In addition to several articles published throughout the year 1946 (see, for example, 'Revoloesi Islam', 13 February and 'Peperangan sekarang soedah djadi fardoel 'ain', 20 April) the magazine also published boxes containing advertising slogans such as SIAP sedia untuk berdjuang fiSabilillah, Djihad Sabil, Daroel Islam itoelah toedjoean kita, Berdjihadlah! FiSabilillah!
} 
by the party's manifesto in June $1947,{ }^{26}$ and maintained well into $1948,{ }^{27}$ further strengthened by the temporary character of the 1945 constitution and by Soekarno's pledge to establish a representative democracy. Masyumi accepted the Republican constitution as a 'stepping stone' towards the realization of Islamic ideals in the state; it recognized Pancasila's harmony with Islamic principles; ${ }^{28}$ and it laid out its domestic and international agendas as a mixture of mild pan-Islamism, democracy and spreading Islamic teachings in Indonesian society through education and dakwah (Islamic propaganda).$^{29}$

In this spirit, over the following months al-Djihad often suggested that Masyumi was the most prominent agent of Islamization of the Republic, and that an Islamic state was the 'logical' solution for Indonesia.

The magazine articulated its dedication to the formation of an Islamic state as such:

If 33 years ago Islam was only a final coating, considered as just enough to function as a link between organizations, now it is not like that. This Masyumi has a 100\% Islamic soul, the spiritual connection among all Masyumi members is Allah's religion, Masyumi's flag is the crescent and the star on a red and white background, Masyumi's aim is the darul Islam, or an Indonesian Republic based on Islam. ${ }^{30}$

Regarding its commitment to parliamentary consultation, it held that:

Now Indonesia is independent, and the Republic is shaped to be based on the people's authority. Although the Constitution does not fulfill yet the desires of the Islamic community, for the time being this is enough, and we are happy and grateful. But Masyumi is aware that the majority of Indonesians are Muslims, and feels

26 'Rencana dari Masjoemi', 20 June 1947, Arsip Kementrian Pertahanan 1946 [hereafter KemPert], no. 1045, ANRI.

27 'Cursus Masjumi’, 27 April 1948, Arsip Kepolisian Negara 1947-1949 [hereafter KepNeg], no. 514, Arsip Nasional Republik Indonesia [hereafter ANRI], Jakarta.

28 As the Pancasila were never modified, this became a common exercise for Muslim intellectuals and scholars in the early 1950s.

29 Noer, 'Masjumi: Its organization', pp. 70-5.

30 'Masjoemi, toelang poenggoeng Republik Indonesia', al-Djihad no. 26, 28 February 1946. This was also worryingly reported by Dutch sources; see ANP-Aneta Bulletin, 'Kentering in de Masjoemi in Indische [archipel]', Documentatie dienst van ANP-Aneta 10 October-27 December 1946, pp. 423-7. 
responsible for their safety and feels obligated to provide them with an Indonesian state based on Islam. ${ }^{31}$

The idea that the 1945 constitution was temporary was also supported by the belief that elections to form a new constitutional assembly (konstituante) would be held soon after the Dutch left the country. This new text, then, had to be drafted following 'the desires of the Islamic community'. It is on these foundations that Masyumi intended to re-open the debate with the secular nationalists whilst at the same time giving its support to Soekarno. Masyumi, in fact, endorsed Soekarno's representative-democratic system, and it based its political opposition on the conviction that the party's large base would - given an electoral opportunity - affirm its political standing and bring forward the necessary changes to establish the Islamic state.

Although Kartosuwiryo's Garut speech, Haloean politik Islam, delivered in June 1946, affirmed mainstream Masyumi policies, his name did not appear among the party's executives at a meeting held in Yogyakarta on 7 November 1946, ${ }^{32}$ perhaps anticipating the fracture with the party board that would ensue later in 1947.

\section{Kartosuwiryo’s Haloean politik Islam}

The Dutch invasion of Java in July 1947 transformed the Priangan into a theatre for total warfare and would push Kartosuwiryo to abandon formal politics. But in mid 1946 he was still participating in the political process in the rank and file of Masyumi, upholding the party's commitment to parliamentary struggle, cooperation and unity. Kartosuwiryo's continuing dedication to the cause was best expressed in a speech he delivered in July 1946 in Garut, later printed by the Dewan Penerangan Masyumi Daerah Priangan (Priangan regional Masyumi Information Office). ${ }^{33}$

After considering the differences between Western and Islamic politics, the pamphlet then focuses on the strategy the ummah should follow to ensure the attainment of God's will on earth (the dar al-Islam) and in the afterlife (the dar al-salam) in the specific historical context of Indonesia's struggle for independence. Following

\footnotetext{
31 'Gemeene Be(e)st kita sabil! Masjoemi haroes djadi Chalifah di Indonesia', al-Djihad no. 26, 28 February 1946. The congress was held in Solo, on 13 and 14 February 1946.

32 Soekiman, Masjkoer, Zainoel Arifin, Djojomartmo, K.H. Abdoel Wahab, Oesman, Mawardi, Soedjono and Dahlan. al-Djihad, 09 November 1946, appended in 'Regerings Voorlichtingsdienst, Government Information Service, D.N. 718', [1946], APG no. 997, NA.

33 Kartosuwiryo, Haloean politik Islam (Garut: Dewan Penerangan Masjoemi, 1946).
} 
a line of thought he had first set out in the late 1920s, Kartosuwiryo insisted that Islam was equally concerned with worldly and eternal salvation, and that only through the establishment of a dar al-Islam could Muslims be guaranteed salvation and admission to the dar al-salam.

The political efforts of the Indonesian ummah were aimed at the establishment of an Indonesian republic based on Islam, in which the government guaranteed the implementation of sharia law in its widest and most complete formulation. Grounding the government in sharia law would allow Indonesia's Muslims to pursue their obligations and would guarantee all Indonesians their freedom from slavery.

Compared with the ideas contained in Kartosuwiryo's writings through the 1920s-1930s, there is nothing new in his describing active participation in the effort to free Indonesia from foreign imperialists as a 'religious duty'. Surely, though, some change in attitude is detectable, as he now encouraged the formation of a unitary front, and supported the parliamentary avenue towards establishing an Islamic state. Conscious of the fact that so many skilled political parties were angling for primacy in the race to control the national government of the soon-to-be independent state, Kartosuwiryo argued that constructive cooperation was the only defence Indonesia had against civil war. Kartosuwiryo realized that the ummah would have much competition in this race, and that it was certainly possible that communism, socialism or nationalism would win. As such, the ummah should strive to build a new world in full conformity with the Qur'an - a dunia Islam or dar al-Islam. He heavily condemned fanaticism, as it "easily threatens the unity of the nation (persatuan bangsa) and the success of the struggle, causing splits and betrayals unwished for at a time when all citizens ought to feel compelled to join in the National Revolution'.

Kartosuwiryo preached the necessity of having 'ideology' to work hand in hand with 'reality'. For Kartosuwiryo, 'ideology' dictated the goals of the effort, while 'reality' determined its means in accordance with the current time and society:

An ideologically driven fighter never stops in his effort to reach and achieve his ideal, maybe once he will appear as running back, jumping right or left, flying west or east because the conditions and reality of society do not allow for anything else, but $[\ldots]$ in his eyes and heart he never left his ideology. ${ }^{34}$ 
In this understanding, the national revolution was a struggle that had to begin inside individual persons before it could move to broader communal and societal contexts on the road to national independence; this was true for Kartosuwiryo, whether the revolution were to be pursued by diplomacy or by weapons. No portion of Indonesia's population was relieved from its duty and responsibility to defend the country and build national sovereignty. But the task that rested solely on the Muslims was the social revolution: a struggle aimed at deconstructing colonialism from within society, thereby effecting a change on the ummah itself. The broader social revolution, however, could only be carried out by those who had already succeeded in the revolution at the individual level and who had fully conformed their souls to Islam.

To Kartosuwiryo, both the national and social revolutions - now explicitly defined as al-jihad al-asghar and al-jihad al-akbar, respectively - were necessary to eradicate colonialism by acting on external (state and government) and internal (citizens' souls) objects of foreign domination. As stated above, modernists and traditionalists developed different strategies to achieve an Islamic state, and Kartosuwiryo concluded that in the current context it would be inappropriate to adhere to dogmatic divisions between social and national revolutions. He suggested instead that the revolutions should be pursued at the same time. Because ensuring de facto and de jure independence was an urgent goal, Kartosuwiryo argued that initially a stronger emphasis was to be placed on the national struggle: the ummah would concentrate its efforts on supporting the physical revolution, while delegating the social revolution to the Islamic leadership. Only once the foreign oppressor had left and Indonesia was free would the rest of the population be involved at the social level.

After independence, the establishment of an Indonesian state based on Islam could be achieved in either a top-down or a bottomup fashion, depending on the ummah's level of representation in, and influence on, national governing bodies. In the first scenario, even though the executive bodies were not dominated by Muslims, those involved in the legislature would have the duty to comply with Islamic regulations, and thus would advance the formalization of an Islamic government. Because of this possible discrepancy between the legislative and the executive bodies, Kartosuwiryo argued in favour of conducting military and political courses for the ummah to ensure a high level of awareness and education at the grassroots level. He also invoked unity and cooperation between ulama and intellectuals, as the former knew the sharia and the latter the rules of government. 
In case this attempt to coordinate hukum, hakim and mahkum (law, judge and sentence) at the national level failed, Kartosuwiryo advanced an alternative strategy: the ummah, still responsible for the implementation of Islamic law at the personal level, would create its own dar al-Islam (note the similarity with the 1938 MIAI speech). Seen as part and parcel of the individual revolution, the involvement of the ummah in legal matters was the first step towards an Islamic social revolution, also called an Islamic people's revolution. It is this social dimension of the ummah's organization and mobilization that Kartosuwiryo had in mind when he established the Darul Islam in 1948.

TROOP POLARIZATION IN WEST JAVA: REPUBLICAN ARMY

AND ISLAMIC MILITIAS FROM THE BRITISH LANDING

TO THE RENVILLE AGREEMENT

While the leaders of the nationalist movement in Jakarta were busy with diplomatic talks, Bandung and the Priangan were gradually becoming the centres of a power struggle for regional control. In May 1946 the Republican government began integrating and rationalizing irregular troops, with the goal of creating a unified army. In the following paragraphs I lay out the premises of this attempt at integration in West Java and the impact of this political decision on the relations between regular soldiers and the Islamic militias. Most skirmishes resulted from the scarcity of weapons; the Islamic militias' disapproval of Republican soldiers' unwillingness to fight; and the Republican soldiers' grudges against the popular support enjoyed by the Islamic militias.

This delicate balance between Republican and Islamic soldiers was further upset by the Dutch invasion of West Java in July 1947. Republican troops and Islamic militias scattered across the Priangan, and as Masyumi was gaining increased footing in the territory, the military confrontation became politicized, with the Republic accusing Masyumi of attempting to become a substitute government. It is in this context that Republican and Islamic troops clashed in Blubur Limbangan and that Kartosuwiryo began the re-structuring of the provincial branch of Masyumi under the name of Darul Islam.

\section{Seeking a structure}

The 3rd Division of the TKR (later to become the Siliwangi Division of Tentara Negara Indonesia, TNI) was initially stationed in 
Tasikmalaya under the leadership of Aroedji Kartawinata (a former PSII cadre; see Chapter 1), but in late October 1945 - just before its command was transferred to Nasution - the division was moved to Malangbong for unspecified 'political priorities'.$^{35}$ Militias operating in the Bandung area had formed the Markas Dewan Pimpinan Perdjoeangan (MDPP, Resistance Leadership Council Headquarter) under the leadership of Soetoko (from Pesindo) and Kamran (Hizboellah leader and future chief of the Tentara Islam Indonesia, TII) as early as January 1946, with the goal of countering the impact of Nasution's Republican troops. ${ }^{36}$

Having broader authority than any of the militia leaders, Nasution began to disarm the MDPP within a month of its formation. He incorporated its soldiers into the TKR and expanded the authority of his own army division. But Nasution did so without considering that the MDPP had been formed with the specific intention of opposing the influence of Republican troops across the region. By the end of February, Kamran and Soetoko formed another coordinating body that was politically neutral and aimed at the establishment of Indonesia's independence. The Majelis Persatoean Perdjoeangan Priangan or Markas Pimpinan Perdjoeangan Priangan (MPPP, Priangan Fighting Unity Council or Leadership Centre) was stationed in Bale Endah, near Ciparay, the most advanced position Indonesian troops had managed to occupy in their struggle for regional defence. ${ }^{37}$

In the meantime, British troops had begun their operation to bring Java under control on behalf of the SEAC. After a few months of long-distance attacks, on 20 March 1946 the 15th Indian Corps of the British artillery heavily attacked the Bandung headquarters of the Tentara Republik Indonesia (TRI, Army of the Indonesian Republic), a group composed largely of Nasution's Siliwangi

\footnotetext{
35 Lukman Madewa, Esa hilang dua terbilang: Album kenangan Kodam 6/Siliwangi 1946-1977 (Bandung: Kodam 6, 1977), p. 24.

36 The MDPP was formed by Pesindo, Hizboellah, Sabilillah, Pemuda Indonesia Maluku, Barisan Banteng and Kebaktian Rakyat Indonesia Sulawesi (Horikoshi, 'The Dar-ul-Islam movement', p. 66) and Barisan Pemberontak Rakyat Indonesia (BPRI), Angkatan Pemuda Indonesia (API), Barisan Merah Putih, Lasjkar Wanita Indonesia (Lasjwi) (Usman Jauhari, 'Peranan Hizboellah-Sabilillah', p. 43. John R.W. Smail, Bandung in the early revolution 1945-1946: A study in the social history of the Indonesian revolution (Ithaca, NY: Department of Asian Studies Cornell University, 1964) offers a detailed investigation of the events that occurred in Bandung between 1945 and 1946 based on Indonesian sources, Siliwangi's military publications and the newspaper Mederka. Madewa, Esa hilang dua terbilang, p. 24. refers to MDPP as Markas Daerah Perjuangan Pertahanan Priangan.

37 Smail, Bandung in the early revolution, pp. 129-30, 143-5; Dinas Sedjarah Kodam VI Siliwangi, Siliwangi dari masa ke masa (Jakarta: Fakta Mahjuma, 1968), p. 505; the second name, 'Leadership Centre', is used in Jauhari, 'Peranan Hizboellah-Sabilillah', p. 42.
} 
soldiers. ${ }^{38}$ Following these attacks, both Siliwangi troops and the MPPP were forced to abandon their positions, allowing the Allies to take control of the city. The MPPP established its new headquarters in East Priangan, which, along with Cirebon, were the only areas controlled by the Republic.

Following a British ultimatum, by the morning of 25 March Nasution had led his TRI division out of Bandung and into Garut. But he added that he 'could not be responsible for extremist elements' ${ }^{39}$ This note is quite significant, as it shows that the level of friction between Nasution and the militias was high, as was his frustration over his inability to control them. The colonel was referring to Hizboellah, Sabilillah and Pesindo militias, which he had unsuccessfully tried to incorporate into his own division for several months. Not only were these militias generally more skilled than the majority of his regular troops, but - and more significantly Nasution was not confident his troops could successfully face the Dutch by themselves, as suggested by Robert Cribb. ${ }^{40}$

The MDPP, too, had moved to Garut, but it had changed its name to become the Resimen Tentara Perdjoeangan (RTP, Fighting Army Regiment), under the exclusive leadership of Soetoko. Within weeks, the RTP was placed under Nasution's Siliwangi Division's command. Also in May 1946, one of its five battalions, composed only of Hizboellah and Sabilillah soldiers and possibly having its origins under Kamran's command, now came under the Command of Major Hoeseinsjah. ${ }^{41}$ This regiment had been able to maintain independence of action for a full year, but by May 1947

38 On 5 October 1945 the president of the Indonesian Republic issued a statement for the formation of the Tentara Keamanan Rakyat; this was transformed once again into the Tentara Keselamatan Rakyat on 7 January 1946 and finally into the Tentara Republik Indonesia on 24 January of the same year. See Jauhari, 'Peranan Hizboellah-Sabilillah', p. 50. Jakarta and Bandung had been occupied by the 7th December Division on 27 August 1946; see MD, AS nos. 2220-2225, NA. For details of British troops movements and the substitution of British troops with Dutch soldiers in Java and Sumatra, see 'The Allied occupation of the Netherlands East Indies, September 1945-November 1946', War Office [hereafter WO] 203/2681; 'War Diaries of the 23rd Indian Division in Java, October 1945 to November 1946', WO 203/6159; 'War Diaries of the 15th Indian Corps January-September 1946', Foreign Office [FO 371/9791]; National Archives of the United Kingdom, Kew [hereafter NAUK].

39 'War Diary, GS Branch, HQ 15 Indian Corps, summary of main events for March 1946', FO 371/9791, NAUK; Madewa, Esa hilang dua terbilang, p. 24.

40 Horikoshi, 'The Dar-ul-Islam movement', p. 67; Robert Cribb, Gangsters and revolutionaries: The Jakarta people's militia and the Indonesian revolution 1945-49, Southeast Asia Publications Series (Sydney: Allen \& Unwin, 1991), pp. 163-6.

41 Jauhari, 'Peranan Hizboellah-Sabilillah', pp. 46, 53. The other battalions were composed of BPRI/Garuda Hitam under Major Riva'i, Pesindo/Taruma Jaya under Major Sudarman and the Bat. Gabungan under Major Pellupessy. 
it was forced to become the 9th Regiment of the 2nd Brigade of Nasution's Siliwangi Division. ${ }^{42}$

Notwithstanding the Republican government's efforts to incorporate irregular militias into the national army, the unification of Siliwangi, Hizboellah and Sabilillah troops was far from happening in reality. The integration and rationalization of irregular militias that began in May 1946 had yet to be achieved by the end of 1947 thanks to widespread tensions and major conflicts. ${ }^{43}$ The order for Hizboellah and Sabilillah troops to merge into the TNI National Army was ratified by Soekarno on 2 January 1948 together with the Renville Agreement, but most of the Islamic militias refused to follow these orders and continued to act as separate armies.

A Pasoendan police report, dated October 1948, regarding the arrest of a former Hizboellah soldier, and later TII lieutenant, exemplifies the problems relating to the integration of Islamic militias into the national army: Doendoeng, originally from the Garut area, had been part of the Japanese Peta, and after the capitulation he had chosen to join Hizboellah to comply with what he felt was his religious duty. During the rationalization process, Doendoeng was incorporated in Hoeseinsjah's battalion and deployed in Cibatu. Six months later he became a TRI lieutenant, soon to be transferred to the Imam Bondjol battalion of the TNI. All this happened despite his open refusal to join the secular Republican forces. He eventually deserted the TNI and again joined Hizboellah when the Islamic militias refused to withdraw to Central Java in January 1948, thus becoming a member of the TII. ${ }^{44}$

Besides the tensions related to individual soldiers' allegiances, frequent skirmishes between Islamic and Republican troops were taking place across the whole region, as the troops were becoming increasingly polarized. The root of these clashes was Hizboellah and Sabilillah's frustration at seeing that TNI troops were better armed but unwilling to fight, as they often abandoned the battlefield, leaving Hizboellah and Sabilillah to face the Dutch. As highlighted in a 1946 police report, when faced with advancing NICA troops, the TNI soldiers stationed in Cibeber retreated, even leaving their weapons behind. Since Hizboellah and Sabilillah were in the area, they picked up the carbines and guns that had belonged to Republican troops and then resoundingly defeated the Dutch.

\footnotetext{
42 Madewa, Esa hilang dua terbilang, p. 25.

43 Abdul Haris Nasution, Sekitar perang kemerdekaan Indonesia, vol. 6 (Bandung: Angkasa, 1978), p. 474.

44 'Proces-Verbaal Doedoeng alias Soenardja, Kementerian Dalam Negeri Negara Pasoendan Afdeeling Politie', 16 October 1948, AABRI DI.
} 
Yet the compiler notes that, on many occasions, retreating TNI soldiers refused to hand their weapons over to Masyumi troops, preferring instead to destroy them as a precaution, since Islamic militias were being treated as enemies. ${ }^{45}$

These clashes increased in frequency and intensity throughout 1946 and 1947, especially after the Dutch invaded West Java in July 1947, and thus mirrored the political conflict between Masyumi and Soekarno's Republican government (discussed below).

\section{The Linggadjati Agreement and the Dutch invasion: Implications for national politics}

The Republicans' readiness to cooperate with the Dutch soon had serious consequences, as several nationalists turned their backs on Soekarno, Sjahrir and their contingencies. The single event that most upset the fragile balance within the anti-colonial movement was the Linggadjati Agreement, signed by Van Mook and the Indonesian Prime Minister, Soetan Sjahrir, in November 1946. Though KNIP eventually ratified it in 1947, the agreement was strongly opposed by Islamic nationalists. The treaty established a ceasefire and called for the formation of a federative United States of Indonesia (with Java, Madura and Sumatra included de facto in Soekarno's Republik Indonesia in Yogyakarta). The federation would be part of the Netherlands-Indonesian Union and under the authority of the Dutch Queen.

The pro-independence front was deeply fragmented among the Islamic, socialist and Soekarnoist factions. However, as the Dutch considered Soekarno, Hatta and Sjahrir to be representative of the movement as a whole, Masyumi was granted less political space than might have been expected from its popular support. ${ }^{46}$

At the end of 1946 Masyumi openly called for armed opposition against a Republican government that pursued overtly accommodationist policies. As announced in a letter sent to all Masyumi branches and published in al-Djihad, Wahid Hasjim, Soekiman and Zainal Arifin proclaimed their intention to 'bring down the Indonesian government with arms'. ${ }^{47}$

45 'Laporan tentang Masjoemi dengan Tentara, Kepala Bagian Penjelidik Republik Indonesia Kantor Polisi Soekaboemi', 20 August 1946, AAS no. 2746, NA.

46 Kahin, Nationalism and revolution, pp. 196 onwards; Ricklefs, A history, pp. 224-5. For a complete analysis of the Federal State, see A. Arthur Schiller, The formation of federal Indonesia, 19451949 (The Hague: Van Hoeve, 1955).

47 'Rapat raksasa Banteng R.I. di Malang, Kementrian Pertahanan Oeroesan A.L.R.I. Bag. C Poesat Jogjakarta', 7 January 1947, KemPert no. 188, ANRI. 
Under such pressure, Sjahrir was forced to resign and Soekarno, to form a new cabinet. In June and July 1947 Soekiman, who had been included in the four-man team in charge of appointing new ministers, demanded leadership of the cabinet and several key ministries for the Islamic party. Soekarno refused to accommodate these demands, and Masyumi withdrew from the cabinet, causing a stalemate only solved in November with the formation of yet another cabinet. ${ }^{48}$

In the meantime, Kartosuwiryo had been invited to represent PSII in the First Amir Sjarifoeddin Cabinet as junior Vice-Minister of Defence. However, while his name was included on the official lists drafted on 3-4 July, as well as on the list published by the press, he never accepted the position. ${ }^{49}$ First, Soekiman, Salim, Kartosuwiryo and Wondoamiseno had not yet completed their attempts to revive the Partai Sarekat Islam Indonesia, thus leaving their relationship with Masyumi undefined. Second, Masyumi was not participating in the cabinet. ${ }^{50}$ Third, Sjarifuddin's cabinet was strongly sympathetic to socialist and communist policies, which did not go down well with Kartosuwiryo.$^{51}$ Finally, I would like to suggest that because the Dutch invasion of July 1947 had led to the physical and political isolation of West Java, Kartosuwiryo's absence from the cabinet was connected with his difficulties (and lack of interest) in joining the centre of parliamentary power. Announcing that he 'had not yet become involved with the PSII and still felt committed to Masyumi', Kartosuwiryo eventually declined Soekarno's and Sjarifuddin's offer ${ }^{52}$

Despite the diplomatic achievements and a climate of relative peace -acknowledged also by the British envoy to Java - on 20 July 1947 the Dutch launched their first military campaign on Republican territory, with the intention of occupying West Java, Madura and Sumatra. ${ }^{53}$ The invading Dutch forces expanded from Bandung

\footnotetext{
48 Noer, 'Masjumi: Its organization', pp. 105-7.

49 'Het Republikeinsche Kabinet Sjarifuddin, IV Kabinet, 3 Juli 1947', APG no. 731, NA; 'Kabinet Sjarifuddin Ve Kabinet (4 Juli 1947-23 Jan 1948)', APG no. 731, NA; 'Kabinet - Sjarifuddin Ve Kabinet (na wijziging op 11-11-1947)', APG no. 731, NA; 'Soesoenan kabinet baroe', Merdeka, 4 July 1947.

50 'Partai Sarekat Islam Indonesia', 19 Mei 1947, KemPert no. 1054, ANRI.

51 'Proces-verbaal van verhoor van R. Didi b.Uhap al.Tatang Bachtiar, Onderhoofd van het Ministerie van Voorlichting van de Negara Islam Indonesia (NII); Parket van den Procureur-Generaal bij den Pengadilan Tinggi van de Negara Pasundan te Bandoeng', 26 September 1949, AAS no. 2755, NA; and Dinas Sejarah TNI, Penumpasan pemberontakan D.I./T.I.I., p. 59. This report of the arrest of a Darul Islam member in 1948 mentions that Kartosuwiryo had refused to join the Sjarifuddin cabinet because it was communist. As this might represent one aspect of the problem, it should also be noted that some anti-communist politicians, including Haji Agoes Salim, joined this cabinet in an effort to bring Indonesia out of its stalemate and to obtain full independence.

52 'Kartosuwiryo keberatan', Merdeka, 8 July 1947.

53 'Bataljion genietroepen oorlogsdagboek nr B149/101.34', MD: AS no. 2231, NA.
} 
across north-eastern West Java in three directions (east, south-east and south-west), pushing Indonesian soldiers and militias south of Purwakarta, Subang, Sumedang and Majalengka. ${ }^{54}$

Regardless of the fact that a United Nations-sponsored ceasefire had been signed in August, the consequences of the invasion were strongly felt in the months to come. On 23 September Netherlands' Prime Minister, Louis Beel, declared that one of the achievements of the politioneele actie ('police action'), as the Dutch called it, had been 'the creation of better conditions for the execution of the political plan of reconstruction laid down in the Linggadjati Agreement'. In fact, Indonesian sources reported that consequent to the invasion, 'All the militias ha[d] left [their headquarters] to reach the various areas of West Java to carry out, at their best, an ideological struggle, sabotage and guerrilla actions.' Rather than supporting Beel's rationale, ${ }^{55}$ such comments showed the irreparable political damage caused by the aggression.

\section{Consequences for West Java}

Dutch troops first arrived in West Java in March 1947 to relieve the British in Cianjur, but connections between the western province and the rest of the island were not severed until early July. ${ }^{56}$

As the Dutch entered Cirebon on 21 July, the Republican police were forced to move south to Ciwaru. When in 1948 the area officially came under Dutch control, the police force was dissolved and its agents offered the opportunity to work for the occupying forces. ${ }^{57}$ This offer, however, was hardly an attractive choice, as it was in fact the only alternative to a forced withdrawal to Yogyakarta or final dismissal from the force. Facing two unsatisfactory options, several officers in Cimahi and Indramayu fled to other villages or to the mountains to avoid forced co-optation in the Dutch ranks. ${ }^{58}$

54 'Laporan keadaan Djawa Barat', 28 July 1947, KemPert no. 1290, ANRI.

55 'Laporan keadaan Djawa Barat', 28 July 1947, KemPert no. 1290, ANRI. Beel's comment in 'Political reconstruction in the Netherlands East Indies, Consul-General Shepherd to Mr. Bevin, Batavia, 22 October 1947', p. 79, FO 480/1, NAUK.

56 'Berita atjara tentang pelaporan R.Legino pembentoe Inspectour Polisian I dari Bandung, RS Joedoprawiro Insp.Polisi II', 30 March 1948, KepNeg no. 526, ANRI. The C division of the 7th December Brigade relieved the British W Brigade in Cianjur.

57 'Berita atjara tentang pelaporan R. Legino', 30 March 1948, and 'Berita atjara tentang Djemino A.P. kl.I dari kantor Kepolisian Keresidenan Cirebon, RS Joedoprawiro Insp.Polisi II', 24 March 1948, KepNeg no. 526, ANRI.

58 'Laporan perdjalanan anggauta Polisi Tjimahi A.P. Kl. I Selam CS dari daerah pendudukan kedaerah Republiek, Mohamad Gondosoebroto', 2 March 1948, KepNeg no. 534, ANRI; 'Berita atjara tentang Ngadiran pegawai Polisi Negara dari Indramaju’, 14 April 1948, KepNeg no. 526, ANRI. 
The Republican police from Bandung, having already been displaced to Ciparay since March 1946, were on 28 July again forced to move, this time to Bongkor (north of Garut), as the Dutch occupied Majalaya and Ciparay. The fall of Leles and Garut in early August caused them to move further to Wanaraja, whilst the Priangan police (usually stationed in Garut) sought refuge in the surrounding mountains, but only after being ordered to destroy all high-rise buildings they encountered en route..$^{59}$ As the Dutch advance from Tasikmalaya had compromised their retreat to Cilawu, the Priangan police did not reach Mount Cikurai until late September, where they hid until Dutch troops found them in mid November $1947 .{ }^{60}$

By now military tensions in West Java had become distributed among the invading Dutch troops, regular Republican Siliwangi soldiers, and those splinters of Sabilillah and Hizboellah militias that had refused to merge with the Republican Army. Despite their rapid expansion, the Dutch lacked territorial control beyond the Cirebon residency. The Republicans had equally limited control, as they ruled only over Liangjulang (Kadipaten). It was Masyumi and its militias that controlled most of the region, with strongholds in the Indramayu and Majalengka regions. ${ }^{61}$

In the Priangan, Masyumi was gradually positioning itself as and assuming the functions of - a local independent government, attracting the attention of the Dutch resident Van der Harst, as well as of Tasikmalaya's chief of police, Said Soerianatanegara. ${ }^{62}$ Masyumi implemented a taxation system in the areas around Indihiang, Mount Cupu and Cisayong in order to buy weapons and supplies for its troops. In addition, the Islamic militias were in the habit of bartering food supplies with starving TNI soldiers in exchange for carbines and guns, as shortages of weapons were occurring across the region. ${ }^{63}$

According to Soerianatanegara, Masyumi's army (namely, Sabilillah and Hizboellah) had as a final goal the establishment of a

59 'Berita atjara tentang pelaporan Soekami Commissaris Polisi dari Bandung, RS Joedoprawiro Insp.Polisi II', 27 March 1948, KepNeg no. 526, ANRI; 'Laporan, Effendi Ardipradja', 24 February 1948, KepNeg no. 534, ANRI.

60 'Laporan, Doelkarnaen', 16 February 1948, KepNeg no. 526, ANRI.

61 'Laporan rahasia Kepolisian Keresidenan Tjirebon', 14 November 1947, Arsip Kabinet Presiden 1950-1959 [hereafter KabPres], no. 1926, ANRI.

62 'Perihal politieke situasi, Kantor Polisi Tasikmalaya', 9 December 1947, KepNeg no. 495, ANRI.

63 'Laporan tentang keadaan didaerah Tasikmalaya Utara, Kantor Polisi Tasikmalaya', 23 December 1947, and 'Perihal keadaan di Tasikmalaya, Kantor Polisi Tasikmalaya', 12 December 1947, KepNeg no. 495, ANRI; 'Politiek-Economisch Verslag betreffende de Residentie Priangan over de maand November 1947, AMK: Rapportage Indonesië 1945-1950 [hereafter RI], no. 327 , NA. 
'New State' (Negara Baru) that would be under the patronage of the Islamic party: 'Until the government comes under Masyumi leadership, there will be no order.' ${ }^{64}$

\section{The Limbangan incident and the nature of the antagonism among Islamic, Republican and Dutch troops}

Continuing the pattern already established in 1946, between September and December 1947 Islamic militias and regular Siliwangi soldiers clashed often in their quest for weapons ${ }^{65}$ and in reaction to the movements of Dutch troops. ${ }^{66}$ As the ceasefire agreement did not require them to withdraw from the positions occupied during their invasion, Dutch troops were stationed all along the line connecting Bandung, Sumedang, Majalengka and Linggadjati.

In September, Endang, the Sabilillah leader in Blubur Limbangan (a village near Cicalengka, Sumedang), had organized a propaganda meeting in Cibuleg. During his speech at the meeting, Endang made some negative comments about the Indonesian Republic, arguing that Sabilillah had to channel its forces towards demolishing the Republic, thereby reinforcing Masyumi's statement made in December 1946. Such comments quickly altered the spirits of some TNI soldiers in Sentot's battalion, who also happened to be attending the meeting, and who felt threatened and offended. Endang and eight of his assistants were thus captured, and the Republican officers agreed that Endang and two of his aides had to be killed under the accuse of treason. The villagers witnessing the events became convinced of the gravity of Endang's statements, agreed on the punishment, apologized for participating at the Sabilillah meeting and swore allegiance to the Republic ${ }^{67}$

At the end of the month, Dutch troops attacked the village of Blubur Limbangan and occupied it. Coincidentally, the Sabilillah group led by Endang's brother was also in the area. To avenge the execution of his brother, Wiganda struck an agreement with the Dutch. Ten days later, several Siliwangi soldiers deployed in the Garut area were summoned to Blubur Limbangan to receive orders. Soon after their arrival, they were made aware that the

\footnotetext{
64 'Laporan tentang keadaan didaerah Tasikmalaya Utara', 23 December 1947, KepNeg no. 495 , ANRI.

65 'Politiek-Economisch Verslag betreffende de Residentie Priangan over de periode 1 tot en met 15 September 1947', AMK: RI, no. 327, NA.

66 'Politiek Economisch Verslag betreffende de Residentie Priangan over de maand October 1947’, AMK: RI, no. 327, NA.

67 '[untitled] folio 7 no. 03409', AABRI DI.
} 
Dutch were about to attack, and to limit the damage inflicted on the civilian population, the TNI dispersed. That same night, the weapons of a local Sabilillah battalion were seized, and two men were found dead. As feelings on the Endang case were still heated, the Sabilillah joined forces with the Dutch troops to capture the Siliwangi officer in charge.

By the time the skirmishes were over, around 350 Masyumi/ Sabilillah members had been arrested in the neighbouring village of Baeud, and the Sabilillah soldiers who had managed to escape joined the Dutch troops. A few days later, a Dutch-Sabilillah patrol of 450 men organized a kidnapping operation in Baeud, which ended in the death of all those captured. The victims, however, were not Siliwangi soldiers, but included Socialist Party members, a Banteng member, a man from the regional inspectorate of Limbangan, civil servants and employees of the Ministry of Forestry.

According to TII lieutenant Syarif Hidayat, in the beginning the Hizboellah were fighting against the Dutch 'colonialists' in support of Soekarno's August 1945 Proclamation. On these grounds, they were incorporated in the Imam Bonjol Battalion of the Republic's TNI. However, Syarif Hidayat vividly recollects TNI's attacks against Hizboellah and Sabilillah soldiers in the Garut and Sumedang areas, and in particular how the events surrounding the killing of Endang had diminished the trust of former Islamic militias in the TNI and the other agencies of the Republic. Inevitably, within a couple of months the chain of events and retaliations spiraled out of control, and clashes spread to Leuwingoong, Malangbong, Pagerageung, Gunung Cupu and the area surrounding Sumedang. ${ }^{68}$

The primary aim of Siliwangi, Sabilillah and Hizboellah troops was the annihilation of colonial power in the archipelago. It is undeniable, though, that friction between Republican and Islamic troops, as well as between secular and religious nationalists, played an important role in directing actions and policies for the next two decades. When in 1962 the Siliwangi Division was conducting sweeps in West Java to cleanse the area of DI-TII soldiers, several of those captured would look back at Blubur Limbangan as the event that had initially set off the antagonism between Islamic and Republican troops. As such, this incident helps us understand how much the dynamics on the ground were dictated by opportunity and necessity, rather than ideology - the latter a concern only the leaders could afford. 


\section{West Java on the eve of the Renville Agreement}

By the end of 1947 the police had singled out Sabilillah troops in Pagerageung and Tasikmalaya as the most fanatic, ${ }^{69}$ and had identified Pagerageung as their military headquarters and Sukawening as their propaganda and political hub. This was the same village where Kartosuwiryo was organizing the party's activities, and Oni coordinated the activities of the Sabilillah. ${ }^{70}$

The first step towards Masyumi's 'New State', was undertaken by the proclamation of a 'Sabilillah Safety Zone' (Sabilillah Keamanan Daerah) on 18 December by a Sabilillah unit which had to relocate to Rancabungur (Indihiang) after Dutch attacks on the Sukawening centre had caused the scattering of Islamic militias across the region. ${ }^{71}$ This initiative further reinforced the Republican government's impression that in the Priangan the population did not recognize Republican authority and instead supported Masyumi.

In theory the Republican authority and Masyumi should not have been in competition with each other. However, the tensions arising from the Republic's negotiations with the Dutch and Masyumi's commitment to building an Islamic state inevitably resulted in them setting their agendas on separate registers. Soerianatanegara went as far as accusing the Islamic party of challenging the Republic at the political and military levels, as Masyumi had been openly discrediting TNI troops whilst praising the bravery of Hizboellah and Sabilillah. Civilians reportedly trusted the Islamic militias more than TNI troops, as it appears that the latter often ran away from combat situations with Dutch soldiers, leaving the fighting to the Islamic militias. Soerianatanegara's explanation was that as civilians were generally more sympathetic to religious militias, these militias were better fed and better armed than the Republic's. ${ }^{72}$

The rise of Islamic politics in the Priangan can only be understood in the context of the complex nature of religious and political authority at the time, as explored in Chapter 1. But Sarekat Islam's and Masyumi's political activism and commitment to the formation of a politically conscious ummah was a key catalyst for

69 'Perihal keadaan di Tasikmalaya', 12 December 1947, KepNeg no. 495, ANRI.

70 'Laporan tentang keadaan didaerah Tasikmalaya Utara', 23 December 1947, KepNeg no. 495, ANRI.

71 'Perihal keadaan di Tasikmalaya', 12 December 1947, KepNeg no. 495, ANRI.

72 'Laporan tentang keadaan didaerah Tasikmalaya Utara', 23 December 1947, KepNeg no. 495 , ANRI. 
popular support and engagement, besides traditional patterns of authority. ${ }^{73}$

According to a Ministry of Defence survey, in the Priangan only the members of Masyumi had a full understanding of the current political situation - here defined as 'total war' - and clear expectations for the path ahead, as they were awaiting the call for perang sabil that would bring Indonesia to independence. ${ }^{74}$ It is in this ideological, military, political and social context that Kartosuwiryo carried out the transformation of Masyumi's West Java division into the Darul Islam movement.

\section{IDEOLOGICAL RADICALIZATION: CALLING FOR HOLY WAR}

The physical isolation of West Java from Republican territories caused by the Dutch invasion in July 1947 laid the foundations for the region's divergent political path to independence, a phenomenon further strengthened by the Renville Agreement. The increasingly ideological characterization of the antagonism between the Republic in Yogyakarta and West Java's regional politics paralleled the polarization of troops on the ground. In the wake of previous Masyumi calls for holy war against the Dutch, in mid August 1947 Kartosuwiryo yet again invoked perang sabil for Muslims in West Java. This call was followed in late September by a national call for jihad fi-sabilillah proclaimed by the central branch of Masyumi.

\section{Kartosuwiryo's Perang sabil}

Marking a dramatic change from his Haloean politik Islam speech, in Perang sabil Kartosuwiryo called upon 'the ummat Islam that feels it a duty to establish a dar al-Islam and fully implement hukum Islam' to rise up against all enemies of religion and the state, the Dutch (Fir'aun Belanda), its NICA employees and Indonesian spies.

73 The police reported that local Masyumi leaders were trying to strengthen their membership's approval by holding public and closed meetings to reinforce the attendants' knowledge of Islam. See 'Laporan tentang keadaan didaerah Karesidenan Priangan, Kantor Kepolisian Karesidenan Priangan', received on 28 February 1948, KepNeg no. 495, ANRI.

74 'Kementerian Pertahanan bagian Perantara Warta dan Publikasi, Ichtisar Laporan no. 5, Daerah Priangan, so'al Totalitaire Oorlog', November 1947, KemPert no. 1073, ANRI. According to this report, members of Pesindo, PPN, PPI and the teachers' organization had very little consciousness of the current situation, whilst members of the socialist and nationalist (PNI) parties and a number of civil servants were mostly aware of the situation but did not understand its implications and consequences. 
Unity and cooperation were no longer under consideration, the secular nationalists were still entertaining diplomatic relations with the aggressive Dutch, and Republican elements were not quite friends and not quite foes. True 'friends of the struggle' were those who shared the goal of a national revolution aimed at establishing an Indonesian state free from colonial domination, regardless of their religious beliefs or political inclinations.

Kartosuwiryo affirmed his hopes that the Indonesian Republic would conform to Islamic ideology in order that it could be part of the dar al-Islam (or dunia Islam) in the form of an Islamic state implementing Islamic laws among its citizens, and thus ensuring their worldly and eternal salvation. Yet he was still open to the possibility that, following the revolution, national authority could be in the hands of other political groups that were representative of whichever ideology the population supported in larger numbers. ${ }^{75}$

Continuing to draw parallels with Muhammad's struggle, Kartosuwiryo associated the Dutch with the Quraysh, Soekarno with the Banu Bakr tribe, and the Linggadjati Agreement with the treaty of Hudaibiyah (628 CE) ${ }^{76}$ In such a framework, the breach of the Hudaibiyah treaty, Muhammad's attack on Mecca and the ummah's subsequent victory over the polytheistic Arab tribes became the key to interpreting the breach of Linggadjati as an opportunity that legitimized the establishment of a fully sovereign and independent Islamic state. This Negara Islam Indonesia would result from the ummah's commitment to taking up arms in a perang sabil, as jihad represented the ummah's effort to build and defend its state and religion.

Recognizing the mixed origins of the term perang sabil, Kartosuwiryo underlined how the Indonesian word perang was attached to the Arabic sabil 'path, way' as the shortened version of fi-sabilillah, 'on the path of God'. This meant 'a war for the defence of the sovereignty of the state, and the purity of religion, a war to fight any attempt to colonization from any nation in any way'. Perang sabil (thus meaning 'war on the path (of God)') or perang suci ('holy war', also bearing the connotation of 'cleansing, purifying')

75 'Keterangan ringkas tentang Perang Sabil S.M. Kartosuwiryo', Arsip Jogja Documenten 1946-1948 [hereafter JogjaDoc] no. 243, ANRI.

76 The treaty of Hudaibiyah was signed in $628 \mathrm{CE}$ by Muhammad and the Quraysh tribe, from which Muhammad himself hailed. The treaty gave individuals and tribes the freedom to choose whether to side with the Quraysh or the Muslims, and allowed Muslims to perform the pilgrimage to Mecca in safety. The following year, the Banu Bakr clan, an ally of the Quraysh, attacked members of the Khuza'a tribe, an ally of Muhammad. Following this breach of the treaty, Muhammad gave the Quraysh three options, from which they chose to end the treaty, hence paving the way for Muhammad's attack on Mecca. 
were identified as specific cases of jihad fi-sabilillah, for which all connected actions were to be pursued with trust in God (tawakkal Allah), and purity of heart and belief (i'tiqad)..$^{77}$

Although it is likely that on this occasion Kartosuwiryo acted on his personal initiative, soon afterwards the central board of Masyumi followed his lead. In late September 1947, former PSII commissar for sharia and 'ibada Kiyai Taoefiqoerachman declared the independence struggle a jihad fi-sabilillah obligatory for all Muslims. He went further, and, mirroring Kartosuwiryo's definition of 'friends of the struggle', the kiyai argued that in addition to those future martyrs who were fighting ' $f$ i sabilillah' to defend Islam, the nation and the territory, there were also those who did not seek the implementation of sharia, but desired to exhibit their bravery, were hot-tempered or simply sought external praise. Making references to Islamic traditions, the text argued that "whoever fights to enhance Islam fights on the path of God', even if Islam is not their religion. Like Kartosuwiryo, Masyumi supported cooperation between Islamic fighters and unbelievers, as long as the latter did not cause harm to the former. ${ }^{78}$

\section{Kartosuwiryo's 'holy war'}

In Kartosuwiryo's writings, the Arabic root j.h.d. assumed several meanings. He strongly opposed Western understandings of jihad as 'war', and thus of Islam as a religion only spread by warfare. In his 1936 Sikap hidjrah, Kartosuwiryo recorded all Qur'anic verses that referred to jihad, explaining each specific asbab al-nuzul (context of revelation) and the term's multiplicity of meanings. Kartosuwiryo focused on the difference between the lesser and greater jihad, arguing for their respective 'negative' and 'positive, constructive' natures. In this context, Sarekat Islam's Program djihad was to be understood as a 'Program for the greater jihad', an effort based on iman and aimed at a successful hijrah by pursuing, searching and obtaining God's mercy and blessing (mengharap, mencari, mendapatkan Rahmat dan Ridhlo). This strategy was divided between the individual duty for each Muslim to study tauhid and the community's efforts, channelled through the party, to achieve political, economic and social improvement. The early spirit of Sarekat Islam was recalled as the basis of this twofold focus:

77 'Keterangan ringkas tentang Perang Sabil S.M. Kartosuwiryo', JogjaDoc no. 243, ANRI.

78 'Pengumuman ke-I Majelis Sjuro Pusat' by Kyai H. Abdul Wahab and Kiyai Taufiqurachman, 27 September 1947, JogjaDoc no. 243, ANRI. 
Since its birth, Partai Sarekat Islam Indonesia (from its origins as Sarekat Dagang Islam to Sarekat Islam until today), has strived to improve the lives and livelihood of the people [...] because a political movement, especially an Islamic political movement, has to take care of, and regulate, economics [...] as these two matters [Islam and economics] must become one. ${ }^{79}$

A decade later, in Haloean politik Islam, the jihad al-asghar is identified with the national revolution, and it is a fard al'ayn. Here Kartosuwiryo is ambiguous on the means for undertaking this jihad. The effort is referred to once as jihad fisabilillah bi ma'na al qital wa al-ghazwa ('struggle on the way of God in terms of fighting and raiding'); another time both armed conflict and diplomacy are listed as valid means for achieving independence. Yet, by September 1947 Kartosuwiryo had dramatically reduced jihad's much wider semantic field, only retaining its 'warfare' meaning.

Kartosuwiryo's narrowing of the meaning of the term jihad through his writings, from Sikap hidjrah to Haloean politik Islam and Perang sabil, was prompted by the changing context in West Java. As first mentioned in Haloean politik Islam, armed jihad in response to an attack on the ummah was the only way to establish a fully independent darul Islam or Negara Islam Indonesia that implemented hukum Islam. The Dutch aggression provided the needed political expedient.

\section{Government reception of Masyumi's and Kartosuwiryo's calls for a jihad}

The declarations encouraging holy war made by Kartosuwiryo and Taoefiqoerachman caught the attention of the Minister of Defence in Yogyakarta, who, incidentally, occupied the position that had been previously offered to Kartosuwiryo. The calls for jihad garnered some positive feedback and indicated that elements of the army and the government were supporting the Islamic struggle, not just as part of the anti-colonial effort but also as a broader ideology. Some support came from Major Kasman Singodimedjo, a former Peta battalion commander, president of the KNIP in Jakarta, Indonesian Procureur Generaal in January 1946, current head of the Defence Ministry's office for military justice and future cabinet minister for Masyumi. Singodimedjo argued that the darul Islam ideology was a 'straightaway right' of the Indonesian Islamic com- 
munity and an indirect right for the government, which had to follow the will of the people. Political participation was a right for the Islamic parties that fought in Indonesia, but religion was in and of itself a right for the entire Islamic community.

Singodimedjo also commented that since Asj'ari's call for jihad in 1945, not only had the Markas Oelama Angkatan Perang Sabil in Yogyakarta followed suit, but several other individuals had also issued calls for a 'holy war'. ${ }^{80}$ The collective enthusiasm for holy war raised two major concerns. First, Singodimedjo argued, 'the time for a general call for holy war was close'. And second, it was still unclear who had the authority to proclaim this 'total' jihad. According to Singodimedjo, politically speaking, the authority should belong to the president as the leader of the KNIP, even though in a strictly religious context this would have been the duty of the imam and his majelis syuro. However, the president had not been recognized as imam, and Islamic parties were deeply involved in politics; Singodimedjo argued that in this situation a 'total' perang sabil seemed unlikely, thus empowering local leaders.

Kartosuwiryo's call for jihad was therefore fully acceptable in religious terms. Furthermore, considering Kartosuwiryo's position as a guerrilla leader in an occupied area, the central government could not 'do anything other than thanking Allah, the One and Only God of the Indonesian Republic, because among his sons are some men as brave and courageous as Kartosuwiryo'. ${ }^{81}$

\section{CONCLUDING REMARKS}

In the aftermath of the Japanese surrender, Soekarno's vision for creating an Indonesian state sidelined, in the name of urgency and necessity, Islamic and leftist requests to consider alternative approaches. It was within this context that the Pancasila gained political favour against Islam and that the 'Jakarta Charter' was

80 Maj. Singodimedjo only mentions the Markas Ulama Angkatan Perang Sabil and Kartosuwiryo. However, I have counted at least four other official acceptances of Hasyim Asy'ari's call, as noted above: the NU congress in Surabaya (October 1945); the motion proposed by the Kaoem Moeslimin Indonesia Angkatan Senjata at the Masyumi congress of Yogyakarta (November 1945); the Moektamar Islam in Bukittingi (December 1945); and the NU congress in Purwokerto (March 1946). To these I would like to add the al-Djihad magazine's propaganda in 1946 and the establishment of the Sabilillah fighting corps (November 1945), both indicators of the surging interest in pursuing an Islamic armed struggle.

81 'Pendapatan saja tentang pernjataan Perang Sabil oleh S.M. Kartosuwiryo', Letter from Gen. Maj. R. Kasman Singodimedjo to Vice-Minister of Defence, Yogyakarta, 22 October 1947, JogjaDoc no. 243, ANRI. 
dropped from the constitution's preamble. Yet, as the 1945 text was to be 'temporary', the religious faction was hopeful that things could still be changed.

Whilst political Islam had lost ground at the national level, Masyumi and its armed wings continued to gain considerable support in the Priangan, at both the military and political levels. The Dutch invasion of West Java in July 1947 and the subsequent diplomatic talks further strengthened this trend, pushing West Java towards independent developments and transforming it into a stronghold of the Islamic nationalist movement. Sabilillah and Hizboellah troops controlled the region, challenging the Dutch as much as the Republican soldiers. Both Kartosuwiryo and the national Masyumi leadership proclaimed a holy war and demanded the establishment of an Islamic state. 